\title{
REKONSTRUKSI TUJUAN PENDIDIKAN ISLAM BERBASIS TAKSONOMI TRANSENDEN
}

\author{
Ah. Zakki Fuad \\ Universitas Islam Negeri Sunan Ampel Surabaya, Indonesia \\ E-mail: zakkif@gmail.com
}

\begin{abstract}
This article focuses on the reconstruction of the objective of Islamic education based on transcendent taxonomy. This study is based on the idea that "the objective of Islamic education is to make students good". The word "good" becomes the key as well as the entrance to formulate the objective of Islamic education by examining the concept of "good" in the Qur'ân. The concept is studied using a model of thematic tafsir (mawdîn) approach. Using this approach, the word "good" is sought through three stems, i.e., the words ahsan-yubsin, saluh-yasluh, and khayr with their various forms and changes in the Qur'ân. The classification of verses uses the theory of taxonomy. This article reveals that the objectives of Islamic education taxonomy can be called the 'transcendent taxonomy.' The objectives of Islamic education based on the Qur'an can be classified into three dimensions: ilâbîyah (theocentrism; divinity), insânyyah (anthropocentrism; humanity), and kawnîah (cosmocentrism; naturality).
\end{abstract}

Keywords: Transcendent taxonomy; the objectives of Islamic education.

\section{Pendahuluan}

Teori-teori pendidikan Barat selalu menjadi rujukan selama bertahun-tahun di Indonesia terutama yang terkait dengan rumusan tujuan pendidikan. Benjamin S. Bloom melalui Bloom Taxonomy, Biggs dan Collis dengan penemuan Taksonomi SOLO (Stucture of Observed Learning Outcomes), serta Kratwohl dan Anderson yang mengembangkan Bloom Taxonomy menjadi rujukan "wajib" bagi praktisi pendidikan di Indonesia dalam menentukan tujuan pendidikan. Di sisi lain pendidikan Islam dengan kekhususannya "terpaksa" mengikuti teoriteori tersebut karena belum ada teori aplikatif yang bisa dijadikan 
rujukan dalam menentukan tujuan pendidikan Islam. ${ }^{1}$

Tujuan pendidikan yang dimaksudkan di sini adalah sesuatu yang diharapkan ketika sebuah proses kegiatan itu selesai, ${ }^{2}$ sementara itu pendidikan, khususnya pendidikan Islam merupakan sebuah kegiatan yang berproses melalui tahapan-tahapan dan tingkatan, maka tujuan pendidikan itu harus sesuai dengan tahapan, klasifikasi tingkatan yang dinamis. Tujuan pendidikan Islam bukan merupakan sesuatu yang statis, tetapi tujuan pendidikan Islam harus berkembang dinamis sesuai dengan situasi dan kondisi peserta didik dan perkembangan zaman.

Ditinjau dari aspek historis, tujuan pendidikan Islam mengalami dinamika seirama dengan kepentingan dan perkembangan masyarakat di mana pendidikan itu dilaksanakan. Seperti halnya tujuan pendidikan di masa Nabi Muhammad dengan dinamika masyarakatnya yang sederhana berbeda jauh dari tujuan pendidikan Islam abad keempat apalagi pada abad modern saat ini. ${ }^{3}$

Perkembangan era inilah yang menyebabkan tujuan pendidikan Islam menjadi dinamis dan transformatif. Terkadang tujuan pendidikan Islam itu juga bersifat ideal-statis dengan ketetapan rumusannya, tetapi derajat kualitasnya berubah dan berkembang. Namun yang harus digarisbawahi adalah bahwa tujuan pendidikan tersebut tidak boleh melepaskan diri dari nilai-nilai ilâhîyah. Melalui

1 Pemahaman term pendidikan Islam sangat beragam di antaranya: pertama, pendidikan menurut Islam atau pendidikan islami, yaitu pendidikan yang dipahami dan dikembangkan dari ajaran dan nilai-nilai fundamental yang terkandung dalam sumbernya, yaitu al-Qur'ân dan al-Ḥadîth. Kedua, pendidikan keislaman atau pendidikan agama Islam, yaitu upaya mengajarkan ajaran agama Islam dan nilainilanya agar menjadi way of life (pandangan dan sikap hidup). Dalam hal ini pendidikan Islam dapat berwujud kegiatan yang dilakukan oleh seseorang atau lembaga untuk membantu seseorang atau sekelompok peserta didik dalam menumbuhsuburkan ajaran dan nilai-nilai keislaman serta segenap fenomena atau peristiwa perjumpaan antara dua orang atau lebih yang dampaknya adalah tertanamnya atau tumbuhnya ajaran Islam dan nilai-nilainya pada beberapa pihak yang terlibat. Ketiga, pendidikan dalam Islam, yaitu proses dan praktik penyelenggaraan pendidikan yang berlangsung dan berkembang dalam sejarah umat, mulai dari budaya dan peradaban era Nabi sampai sekarang. Dari ketiga istilah tersebut pada substansinya adalah sama, yaitu pendidikan yang mereduksi dari ajaran Islam melalui al-Qur'ân dan al-Ḥadîth serta sîrah nabi dan peradabannya. Muhaimin, Paradigma Pendidikan Islam: Upaya Mengefektifkan Pendidikan Agama di Sekolah (Bandung: Rosdakarya, 2001), 29.

2 Zakiyah Daradjat, Ilmu Pendidikan Islam (Jakarta: Bumi Aksara, 2009), 29.

3 M. Amin Abdullah, Falsafah Kalam di Era Postmodernisme (Yogyakarta: Pustaka Pelajar, 1995), 10-13. 
dinamika ini, para ahli pendidikan Islam pun berbeda dalam menentukan rumusan pendidikan Islam. Antara ahli satu dengan yang lain berbeda pandangan sesuai disiplin ilmunya masing-masing serta latar sosial mereka yang beragam.

Sekarang ini, tujuan pendidikan Islam banyak dirumuskan sesuai dengan keinginan guru, program institusi, kepentingan penguasa negara dan pembuat kebijakan, hasil konferensi, hasil lokakarya, hasil kongres, seminar ${ }^{4}$ maupun pesanan ideologi tertentu yang terkadang kurang mempertimbangkan landasan filosofis dan sumber nilai-nilai ilâhŷah dari perumusan tujuan pendidikan itu sendiri.

Bukti bahwa kepentingan penguasa negara Indonesia berpengaruh pada tujuan pendidikan adalah transformasi rumusan tujuan pendidikan sejak zaman Orde Lama, Orde Baru, dan era reformasi sekarang ini. Rumusan tujuan pendidikan yang secara makro lebih dikenal dengan tujuan pendidikan nasional selalu mengalami perubahan substantif dari masa ke masa. Hal ini mengakibatkan tujuan pendidikan nasional selalu berubah sesuai dengan kepentingan pembuat rumusan tersebut.

Persoalan-persoalan di atas menjadi dasar pentingnya kajian ini dilakukan untuk mencari jawabannya dengan cara menggali langsung dari wahyu Tuhan, yaitu al-Qur'ân. Hal ini karena al-Qur'ân memuat banyak aspek keilmuan yang masih belum digali. Dengan menggunakan metode tafsir tematik (mawdûu) penulis mencoba menemukan teorisasi taksonomi tujuan pendidikan Islam perspektif alQur'ân dan urgensi teori tersebut bagi praktik pendidikan Islam.

Pada dasarnya taksonomi sendiri merupakan klasifikasi khusus yang berdasar pada data penelitian ilmiah mengenai hal-hal yang diklasifikasi secara sistemik. ${ }^{5}$ Salah satu klasifikasi khusus yang dimaksud dalam penelitian ini adalah klasifikasi tujuan-tujuan pendidikan. Tujuan pendidikan menunjukkan apa yang harus dicapai peserta didik sebagai hasil belajar yang dituangkan dalam "rumusan eksplisit untuk mengubah performa peserta didik melalui proses

\footnotetext{
${ }^{4}$ Seperti kongres Second World Conference on Muslim Education, International Seminar on Islamic Concepts and Curricula, Recommendation, 15 to 20", March 1980, Islamabad, Seminar Pendidikan Islam se-Indonesia tangal 7-11 Mei 1960 di Cipayung, Bogor. Kegiatan ini berusaha merumuskan tujuan pendidikan Islam yang diharapkan bisa dipakai oleh lembaga pendidikan Islam.

5 Anderson, International Encyclopedia of Teaching and Teacher Education (Oxford: Pergamon Press, 1995), 17.
} 
pendidikan". ${ }^{6}$ Adapun taksonomi yang banyak dikenal di dunia pendidikan di Indonesia di antaranya adalah Taksonomi Bloom, Taksonomi SOLO (Structure of Observed Learning Outcomes), dan Taksonomi Cogaff (kognitif dan afektif).

Membuat teori taksonomi berarti menglasifikasi sebuah temuan keilmuan, memetakan, dan mengategorikan dengan unsur bahasa yang bisa dipahami, seperti klasifikasi kecil sampai besar, klasifikasi mudah sampai sulit, klasifikasi ringan sampai berat, klasifikasi lama sampai baru, klasifikasi tradisional sampai modern, klasifikasi rendah sampai tinggi, klasifikasi bawah sampai atas atau sebaliknya. ${ }^{7}$

Klasifikasi-klasifikasi yang didasarkan pada teori taksonomi itu nantinya akan disusun secara sistematis, hirarkis, dan kategorik sehingga bisa dipakai secara aplikatif untuk kebutuhan dalam merumuskan tujuan pendidikan Islam dalam perspektif al-Qur'ân. Intinya, tujuan pendidikan Islam yang akan ditemukan dalam penelitian ini merupakan klasifikasi data-data yang diperoleh dari alQur'ân tentang tujuan pendidikan Islam itu sendiri.

\section{Skema Taksonomi Transenden}

Taksonomi Transenden merupakan temuan baru terkait dengan tujuan pendidikan Islam yang bersumber dari al-Qur'ân dengan

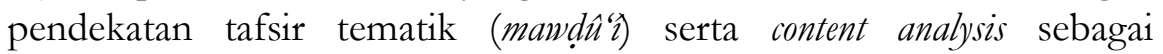
pendukung dalam analisis data.

Konsep Taksonomi Transenden dimulai dari sebuah pemikiran filosofis bahwa "tujuan pendidikan Islam harus menjadikan peserta didik menjadi baik (orang baik)". Kata "baik" ini adalah kunci dan pintu masuk dalam merumuskan tujuan pendidikan Islam dalam penelitian ini dengan cara meneliti konsep "baik" dalam al-Qur'ân melalui tiga akar kata, yaitu kata ạ̣san yubsin dan șaluh yas suḅ serta kata khayr dengan berbagai bentuk dan perubahannya dalam al-Qur'ân. Kemudian dari tiga akar kata tersebut ditelusuri lagi akar kata yang

\footnotetext{
${ }^{6}$ Orin W. Anderson dan David R. Krathwohl, A Taxonomy for Learning, Teaching and Assassing: A Revision of Bloom's Taxonomy of Educational Objective (New York: Longman Press, 2001), 4.

7 Seperti dalam taksonomi tumbuhan yang ditulis oleh Joseph Pitton de Tournefort pada tahun $1716 \mathrm{M}$ yang berjudul Institutiones Rei Herbariae yang menglasifikasikan tumbuhan dari bawah ke atas menjadi genus (marga), familia (suku), ordo (bangsa), classis (kelas), division (divisi), dan regnum (dunia). Lihat Gembong Tjitrosoepomo, Taksonomi Umum, 63.
} 
mempunyai korelasi dengan ayat lain sampai ditemukan klasifikasi "baik" dalam al-Qur'ân. ${ }^{8}$

Kata aḅsan yuhsin dengan segala perubahannya dalam al-Qur'ân disebut sebanyak 200 kali. Sedangkan kata saluh yașlụ̣ dengan berbagai bentuk dan perubahannya disebut 180 kali. Sementara itu al-Qur'ân menyebut kata khayr sekitar 109 kali.

Sebenarnya selain tiga akar kata tersebut, al-Qur'ân juga memakai kata al-birr dan kata al-ma'rûf untuk term "baik", tetapi dua kata ini tidak banyak disebut dalam al-Qur'ân dan tidak memiliki korelasi serta signifikansi dengan tema yang diteliti. Pencarian akar kata al-birr dan kata al-ma'rûf dengan segala perubahan dalam al-Qur'ân hanya disebut kurang dari 10 ayat. Berikut ini adalah penjelasan dari tiga kata kunci di dalam al-Qur'ân yang memiki makna "baik/kebaikan" dan "orang baik".

\section{Kata absan-yubsin}

Kajian dan penelitian ayat-ayat tentang "baik" dengan akar kata ahsan-yubsin menemukan indikator orang baik atau orang yang berbuat baik (mubsinin) di antaranya tertulis pada:

Pertama, al-Qur'ân 2:195. Ayat ini berisi tentang beberapa perbuatan baik yang dikehendaki oleh Allah melalui kata aḥsinû, yaitu manusia diperintahkan untuk selalu berbuat baik. Macam-macam perbuatan baik pada ayat tersebut di antaranya adalah membelanjakan harta di jalan Allah. Jika seseorang membelanjakan harta di jalan Allah, maka Allah akan melipatgandakan apa yang sudah dibelanjakannnya. ${ }^{9}$ Selain itu Allah juga menjamin harta tersebut akan berkembang dan tidak akan habis karena ia terjaga di jalan yang benar. Ayat ini juga melarang manusia untuk tidak menjatuhkan diri kepada kebinasaan. ${ }^{10}$

8 Penelusuran akar kata dalam penelitian ini menggunakan Software The Holy Qur'ân versi 7.10, Harf information Tecnology co. tahun 2000 M. Afẓalur Rahman, Indeks al-Qur'ân (Jakarta: Amzah, 2009), Fuâd 'Abd al-Bâqî, Mu'jam al-Mufahrâs li Alfâzal-Qur'ân (Kairo: Dâr al-Fikr, 1992).

${ }_{9}$ al-Qur'ân, 2: 261.

${ }^{10}$ Menjatuhkan diri dalam kebinasaan dalam ayat ini dipahami sebagai penyimpangan atau hilangnya nilai positif yang melekat pada sesuatu tanpa diketahui kemana perginya. Nilai positif tersebut di antaranya adalah keyakinan akan keesaan Tuhan, kemerdekaan dan kebabasan hidup, serta ketenangan lahir dan batin dalam kehidupan yang dijalani oleh manusia. M. Quraish Shihab, Tafsîr al-Miṣbâh, Pesan, Kesan dan Keserasian al-Qur'ân, Vol. 1 (Jakarta: Lentera Hati, 2000), 397-398. 
Sementara itu, makna kata absinû atau berbuat yang baik seperti yang disabdakan oleh Nabi Muhammad adalah "Menyembahlah Allah seakan-akan melihat-Nya dan bila tidak tercapai maka yakinlah bahwa Dia melihatmu". Hal ini berarti bahwa sebagai manusia kita harus menyadari bahwa setiap aktivitas dan langkah kita harus selalu berada di jalan Allah karena Dia selalu mengawasi kita. Inilah kesadaran paling penting yang menjadikan manusia selalu ingin berbuat baik kepada orang lain maupun kepada dirinya sendiri. ${ }^{11}$ I $h$ sân dalam ayat ini juga lebih tinggi derajatnya daripada adil, karena adil adalah mengambil semua hak kita dan memberikan semua hak orang lain, tetapi ihsân adalah memberi orang lain lebih banyak dan mengambil hak kita lebih sedikit. Oleh karena itu, pada ayat di atas dinyatakan bahwa Allah menyukai orang yang berbuat ị̣sân.

Kedua, al-Qur'ân 4:125. Kata mubsinûn pada ayat ini berbeda menurut para mufassir dari ayat pada poin "a" dia atas walaupun secara substansi masih memiliki kesamaan. Al-Tabarî mengemukakan makna muḅsinûn dengan âmil bimâ amar bih rabbah, muharrim mâ ḥarrmah, mubill mâ hallalah. ${ }^{12}$ Sedangkan al-Râzî memaknai mubsinûn dengan fíl alhasanât wa tark al-sayyi'ât. ${ }^{13}$ Sedangkan M. Quraish Shihab memberikan makna mubsinûn dengan orang mukmin yang selalu mawas diri dan merasakan kehadiran Allah. ${ }^{14}$ Jadi pada dasarnya orang yang baik adalah orang yang selalu menjalankan perintah-perintah Allah menjaga diri dari hal-hal yang diharamkan dan mencari sesuatu yang halal semata untuk kehidupannya. Hal tersebut jika dilakukan akan menyebabkan manusia dapat merasakan kehadiran Tuhan di dalam kehidupannya. Inilah yang dinamakan mubsinûn.

Ketiga, al-Qur'ân 5:13. Ayat ini menjelaskan bahwa Allah menyukai orang-orang yang berbuat baik (muhsinin). Pada konteks ini mubsinin adalah orang yang memaafakan kesalahan orang lain yang terkait dengan persoalan pribadi, karena perilaku muḅsinin dalam hal ini

Tidak menjatuhkan diri kepada kebinasaan juga bermakna menegakkan profesionalisme dan membelanjakan harta secara proporsional. Ibn Kathîr, Tafsir alQur'ân al-'Ažîm (Damaskus: Dâr al-Ṭayyibah, 1999), 528.

${ }^{11}$ Shihab, Tafsîr al-Mişbâh, 399.

12 Abû Ja'far al-Tabarî, Jâmi al-Bayân fí Ta'mîl al-Qur'ân, Vol. 1 (Kairo: Mu'assasat alRisâlah, 2000), 250.

${ }^{13}$ Fakhr al-Dîn al-Râzî, Mafâtị̂ al-Ghayb (Beirut: Dâr al-Fikr, 1981), 393.

${ }^{14}$ Shihab, Tafsîr al-Miṣâh, 573. 
adalah membalas keburukan dengan kebaikan. ${ }^{15}$

Keempat, al-Qur'ân 5:93. Dalam ayat ini Allah menyukai orang yang berbuat baik (mubsinin), yaitu orang yang sudah melakukan amal saleh, beriman dan bertakwa kepada Allah. Al-Muhsinin merupakan gelar tertinggi yang diyakini oleh banyak ulama karena ia lebih tinggi derajatnya dari adil. Muḅsinîn di mata Allah adalah orang yang diberi lebih banyak daripada yang dia inginkan.

Kelima, al-Qur'ân 11:115. Kandungan ayat ini menyatakan bahwa "Allah tidak akan menyia-nyiakan amal orang mubsinîn". Orang yang muhsinin adalah orang yang selalu istiqâmah serta melaksanakan salat dalam kehidupannya sehari-hari. ${ }^{16}$

Kesimpulan penelusuran dari akar kata absan-yubsin tentang indikator orang baik atau perbuatan baik yaitu infak di jalan Allah, menyembah Allah, berperilaku positif, yakin atas keesaan Allah, kemerdekaan hidup, kebebasan, ketenangan hidup lahir batin, ikhlas, menjalankan perintah Allah, menjauhi larangan Allah (al-Qur'ân 2:195); memaafkan, membalas keburukan dengan kebaikan (al-Qur'ân 5:13); beriman, bertakwa, beramal saleh (al-Qur'ân 5:93), istiqâmah dan sabar (al-Qur'ân 11:115).

\section{Kata salub-yaslub}

Kata saluh-yasluh dengan berbagai bentuk dan perubahannya dalam al-Qur'ân disebut di antaranya pada:

Pertama, al-Qur'ân 2:11. Kata muslihûn yang terdapat pada ayat ini bermakna orang-orang yang memelihara nilai-nilai sesuatu sehingga kondisinya tetap tidak berubah sebagaimana adanya, sehingga hal itu

\footnotetext{
15 Pemahaman kata "memaafkan" dalam ayat ini adalah khusus berkaitan dengan halhal yang tidak merugikan dakwah Islam, bahkan menunjukkan keistimewaan Islam sebagai agama yang sempurna dibanding agama lain yang ada sebelumnya sehingga mereka (orang-orang kafir) merasa tertarik dan simpati kepada nabi Muhammad serta ajaran yang dibawa oleh beliau. Memaafkan juga termasuk hal-hal yang bersifat kesalahan pribadi, termasuk hal-hal yang menyakiti nabi secara personal seperti upaya orang kafir menyihir beliau. Shihab, Tafsîr al-Mișbâh, Vol. 3, 14.

16 al-Harali sebagaimana dikutip al-Biqâłi menyatakan, bahwa mubsinîn adalah puncak kebaikan amal perbuatan. Bagi seorang hamba sifat mubsinîn tercapai saat seorang memandang dirinya dan orang lain, sehingga ia lebih baik memberi lebih banyak daripada menerima. Sedangkan mubsinîn antara hamba dan Allah adalah leburnya dirinya sehingga ia hanya "melihat" Allah. Adapun mubsinîn antara hamba Allah dengan sesama menusia adalah bahwa dia hanya melihat orang lain memberikan kebutuhan orang lain dibanding kebutuhannya sendiri. Shihab, Tafsîr al-Miṣbâh, Vol. 6, 357; al-Tabarî, Jâmi al-Bayân, 526.
} 
tetap berfungsi dengan baik dan bermanfaat. Orang-orang yang masuk kategori muslibûu adalah orang yang menemukan sesuatu yang hilang atau berkurang nilainya, tidak berfungsinya sesuatu, kurang manfaatnya sesuatu kemudian melakukan aktivitas (memperbaiki) sehingga sesuatu itu bisa menyatu kembali. Perbuatan tersebut lebih baik bagi siapa yang menemukan sesuatu yang bermanfaat dan berfungsi dengan baik, kemudian ia melakukan aktivitas yang melahirkan nilai tambah bagi sesuatu itu sehingga kualitas dan manfaatnya menjadi bertambah serta lebih tinggi dari semula. Inilah kualitas muslibûn yang sebenarnya. Ibn Jawzî memberikan makna muslihûn sebagi orang-orang yang tidak mengerjakan sesuatu yang menjadikan kerusakan. ${ }^{17}$

Kedua, al-Qur'ân 3:114. Kata al-sâlihîn pada ayat ini dimaknai dengan "Orang-orang yang memelihara nilai-nilai luhur yang diamanatkan oleh Allah". ${ }^{18}$ Indikator orang yang memelihara nilai-nilai luhur yang diamanatkan oleh Allah dalam ayat ini adalah orang yang selalu membaca ayat-ayat Allah pada waktu malam hari, beriman kepada hari akhir, menyuruh orang untuk berbuat kebaikan dan menjauhi larangan Allah serta tidak bermalas-malasan dalam menjalankan ibadah kepada Allah. Al-Alûsî memahami kata al-sâliḩîn dalam ayat ini dengan orang-orang yang berperilaku baik dalam pandangan Allah. Perilaku yang baik dalam pandangan Allah adalah semua tindakan yang sesuai dengan ajaran-ajaran Islam yang dibawa oleh Nabi Muhammad. ${ }^{19}$

Ketiga, al-Qur'ân 9:75. Orang-orang saleh (sâlihîn) pada ayat ini adalah orang-orang yang melakukan kebaikan dan perbaikan. ${ }^{20}$

${ }^{17}$ Ibn al-Jawzî, Zâd al-Masîr fì Tlm al-Tafsîr (Kairo: Dâr Ibn Hazm, 2013), 3. Ayat tersebut diturunkan tentang perilaku orang munafik yang selalu melakukan kerusakan yang ada di bumi. Bentuk-bentuk pengerusakan yang dilakukan di antaranya; Pengerusakan terhadap dirinya sendiri dengan cara ketika dia sakit mereka enggan berobat sehingga sakitnya semakin parah. Pengerusakan terhadap anak-anak dan keluarganya dengan cara menularkan sifat-sifat yang buruk kepada anak dan keluarganya. Pengerusakan terhadap masyarakat dengan cara menyebarkan isu-isu negatif, menanamkan kebencian dan perpecahan di masyarakat. Shihab, Tafsîr alMiṣbâh, 101-102.

18 Shaykh Mutawallî al-Sha'rawî memahami orang salihîn pada ayat di atas dengan Ahli Kitab yang baru masuk Islam. Shihab, Tafsîr al-Mișbâh, Vol. 2, 178.

${ }^{19}$ Shihâb al-Dîn Maḥmûd al-Alûsî, Rủh al-Ma'ânî fî̀ Tafsîr al-Qur'ân al-Karîm wa Sab'alMathânî (Beirut: Dâr Ihyyâ' al-Turâth al-'Arabî, 2008), 64.

${ }^{20}$ Ibn Kathîr menyatakan sebab turunnya ayat ini adalah ketika seseorang dari kelompok Anșâr, yaitu Tha'labah b. Hathib al-Anșârî, ketika itu memohon kepada Nabi untuk didoakan mendapat rejeki yang melimpah. Nabi kemudian mengingatkan 
Indikator orang saleh dalam konteks ini adalah orang yang bersedekah setelah ia mendapat karunia dari Allah. Orang yang sâlibîn adalah orang yang berbuat baik dengan hartanya dan orang-orang yang bersilaturahmi. ${ }^{21}$ Orang yang salihîn pada ayat ini lebih condong kepada kesadaran akan kepeduliannya dengan orang lain (kesalehan sosial), yaitu memberikan sedekah kepada sesamanya dan menyambung tali persaudaraan kepada saudara-saudaranya Muslim. Kesadaran bahwa harta yang ia miliki pada hakikatnya adalah milik Allah menyebabkan ia sadar bahwa di dalam harta itu juga ada hak-hak orang lain yang harus diberikan.

Hasil penelusuran melalui kata kunci saluh-yașluh menyatakan bahwa indikator orang baik atau perbuatan baik yaitu tidak membuat kerusakan di bumi (al-Qur'ân 2:11), iman kepada Allah, iman kepada hari akhir, menyuruh berbuat baik, mencegah kemungkaran, cepat dalam melaksanakan kebaikan, membaca al-Qur'ân di malam hari (alQur'ân 3:114), sedekah dan silaturahmi (al-Qur'ân 9:75).

3. Kata khayr

Dari 109 ayat yang diteliti ditemukan ayat-ayat yang menjadi indikator orang baik atau perbuatan baik yang terdapat pada:

Pertama, al-Qur'ân 2:184. Kata khayr yang tertulis pada ayat ini dipakai dalam konteks berpuasa. Secara spesifik khayr (baik atau perbuatan baik) dipakai untuk orang yang dengan kerelaan hati mengerjakan kebajikan serta orang-orang yang ikhlas menjalankan puasa hanya karena Allah. Al-Naysâbûrî memahami khayr lah pada ayat di atas yang dikehendaki adalah puasa. ${ }^{22}$ Puasa yang dikehendaki pada ayat tersebut kemudian di-munâsabah-kan dengan al-Qur'ân 2:185 yang intinya menjelaskan bahwa puasa itu berlaku untuk orang tertentu dan dalam waktu tertentu pula. Puasa berarti menahan diri.

bahwa; "Sedikit yang disukuri itu lebih baik daripada banyak tapi tidak disukuri". Namun ia tetap memohon sambil berjanji akan memberi kepada siapa yang berhak diberi. Nabi kemudian mendoakannya hingga kambing gembalaannya semakin berlipat ganda dan ia menjadi kaya raya. Karena kesibukannya mengurus harta kekayaannya ia tak lagi melaksanakan salat jemaah kecuali hari Jumat. Ketika turun ayat yang memerintahkan Nabi mengumpulkan zakat, Tha'labah pun enggan mengeluarkan zakat. Kemudian turunlah ayat ini. Ketika Tha'labah menyesal dan bersedia membayar zakat, maka Nabi menolak menerima zakatnya. Shihab, Tafsîr alMiṣbâh, Vol. 5, 658. Ibn Kathîr, Tafsir al-Qur'ân al-Ažîm, 99.

21 al-Tabarî, Jâmi al-Bayân, 199.

${ }^{22}$ Nizâm al-Dîn al-Ḥasan b. Muhammad b. Husayn al-Qummî al-Naysâbûrî, Gharâib al-Qư'ân wa Raghâib al-Furqân, Vol. 1 (Beirut: Dâr al-Kutub al-'Ilmîyah, 2010), 377. 
Menahan diri ini berlaku untuk semua orang, baik yang kaya, miskin, muda, tua, orang modern maupun orang terdahulu.

Kedua, al-Qur'ân 2:215. Ayat ini menjelaskan tentang tata cara menafkahkan harta kekayaan yang diperoleh manusia di dunia ini. Harta yang dinafkahkan harus sesuatu yang baik (khayr). Harta yang baik yang dikehendaki dalam ayat ini adalah harta yang halal serta digunakan untuk tujuan-tujuan yang baik dan bermanfaat. Sedangkan untuk menafkahkan sesuatu (anfaqtum min khayr) harus kepada orang yang berhak, di antaranya adalah kerabat, anak-anak, pembantu, dan sabîl Allâh. ${ }^{23}$

Ketiga, al-Qur'ân 2:220. Kata khayr pada ayat ini dipakai dalam konteks pemeliharaan anak yatim. Perbuatan yang termasuk dalam kategori khayr (baik) adalah mendidik, bergaul, memelihara serta mengembangkan harta mereka secara baik dan wajar. Ayat ini turun karena sebelumnya orang-orang dari para sahabat Nabi merasa kesulitan menjaga dan memelihara anak yatim, karena pada saat itu mereka memisahkan makanan anak yatim dengan makanan yang mereka makan, jika masih tersisa mereka menyimpannya dan terkadang menjadi basi.

Keempat, al-Qur'ân 2:263. Ayat ini menjelaskan dua hal yang termasuk perbuatan khayr, yaitu perkataan yang baik dan pemaaf. Perkataan yang baik adalah ucapan yang menyenangkan dan tidak menyakiti hati orang yang meminta atau perkataan yang sesuai dengan budaya terpuji serta norma yang berlaku dalam masyarakat. Sedangkan pemberian maaf dalam hal ini juga dalam konteks memberikan maaf pada peminta-minta yang terkadang sedikit memaksa. Al-Samarqandî memaknai qawl ma'rûf dengan doa seseorang kepada saudaranya yang lain. Sedangkan maghfirah dimaknai dengan memberikan maaf kapada orang yang menzalimi dirinya dan itu merupakan sedekah yang paling baik bagi dirinya. ${ }^{24}$ Kedua perbuatan inilah yang masuk kategori khayr.

Kelima, al-Qur'ân 2:271. Ayat ini menjelaskan tentang perbuatan yang masuk dalam kategori khayr, yaitu keikhlasan dalam bersedekah kepada fakir miskin. Keikhlasan merupan sesuatu yang sangat rahasia bagi umat manusia, karena hanya Allah yang mengetahuinya. Dalam hal ini, keikhlasan tidak bisa dilihat dan dinilai secara fisik (aspek lahir), maka bersedekah dengan terang-terangan-sebagaimana

\footnotetext{
${ }^{23}$ al-Râzî, Mafâtîh al-Ghayb, 33.

${ }^{24}$ Abû al-Layth Naṣr al-Dîn Muhammad b. Aḥmad b. Ibrâhîm al-Samarqandî, Bạ̣r al-Ulùm (Beirut: Dâr al-Kutub al-'Ilmîyah, 2010), 44.
} 
disebutkan dalam ayat tersebut—adalah perbuatan baik selama ia bertujuan untuk mendorong orang lain ikut bersedekah dan bukan diniatkan untuk pamer (riyâ). Akan tetapi bersedekah dengan sembunyi-sembunyi itu lebih baik supaya tidak ada pamrih di dalamnya dan hanya karena Allah.

Keenam, al-Qur'ân 4:25. Kata khayr lakum pada ayat ini dikaitkan dengan kesabaran manusia yang berhubungan dengan lawan jenisnya. M. Quraish Shihab memaknai khayr lakum adalah kesabaran supaya tidak terjerumus kepada zina. Sedangkan al-Mâwardî (w. $450 \mathrm{H}$ ) memahami sabar dengan keteguhan hati untuk tidak menikahi budakbudak wanita. ${ }^{25}$ Sebenarnya, konteks ayat tersebut berkaitan dengan orang-orang Islam yang hendak menikahi para budak wanitanya. Sedangkan untuk menikahi budak tersebut diperlukan beberapa persyaratan, yaitu tidak memiliki kecukupan biaya untuk mahar istri seorang wanita merdeka dan kebutuhan hidup suami istri serta kekawatiran terjerumus ke dalam zina. Jadi pada dasarnya kesabaran yang termasuk perbuatan baik adalah sabar untuk tidak menikahi budak dan kesabaran untuk tidak melakukan zina.

Ketujuh, al-Qur'ân 4:59. Konteks ayat ini berkaitan dengan pengambilan sebuah hukum di mana umat Islam diperintahkan untuk taat kepada Allah, Rasul-Nya serta ulu al-amr ${ }^{26}$ dalam kehidupannya di dunia. Jika ada pertentangan di antara mereka, maka harus dikembalikan kepada al-Qur'ân dan al-Hadîth. ${ }^{27}$ Berpegang teguh pada al-Qur'ân dan al-Hadîth itu merupakan perbuatan khayr.

Kedelapan, al-Qur'ân 4:114. Kata khayr pada ayat ini dipakai dalam kaitannya dengan tiga hal, yaitu perintah bersedekah, amr bi al-ma'rûf (perintah berbuat baik) dan perintah mengadakan perdamaian antar manusia. $^{28}$

25 Abû al-Ḥasan 'Alî b. Muḥammad b. Muhammad b. Ḥabîb al-Baṣrî al-Baghdâdî alMâwardî, al-Nukat wa al-Uyûn (Beirut: Dâr al-Kutub al-'Ilmîyah, 2010), 82. Shihab, Tafsîr al-Mişbâh, Vol. 2, 387.

26 Pendapat ulama berbeda tentang makna ûli al-amr, ada yang mengatakan mereka adalah orang-orang yang berwenang mengurus urusan kaum Muslim. Ada juga yang mengatakan mereka adalah orang-orang yang diandalkan dalam menangani persoalan-persoalan kemasyarakatan seperti pemerintah. Tetapi ada yang mengatakan mereka adalah para ulama. Pendapat lain yaitu mereka adalah orang-orang yang mewakili masyarakat dalam berbagai kelompok dan profesinya. Shihab, Tafsîr alMiṣbâh, Vol. 2, 461.

27 al-Mâwardî, al-Nukat wa al-Uyûn, 87.

${ }^{28}$ Jalâl al-Dîn al-Mahallî dan Jalâl al-Dîn al-Suyûtîn, Tafsîr Jalâlayn wa Lubâb al-Nuqûl fî̀ Asbâb al-Nuzûul 'alâ Hâmish al-Qur'ân al-Karîm (Kairo: Dâr Ibn Kathîr, 2008), 97. 
Kesembilan, al-Qur'ân 7:85. Kandungan ayat ini berkaitan dengan beberapa hal yaitu tentang tauhid (iman kepada Allah), tentang kejujuran dalam bertransaksi dagang dan larangan membuat kerusakan di muka bumi. Tiga kandungan ayat tersebut dipahami sebagai perbuatan khayr di sisi Allah. Al-Biqầî memahami bahwa dhâlikum khayr lakum adalah aktivitas yang didasarkan pada keimanan dan akan mendapat pahala dari Allah. Tabatabâ'i, seperti yang dikutip oleh M. Quraish Sihab, memahami bahwa perbuatan khayr dalam ayat ini di antaranya adalah menyempurnakan takaran atau timbangan, karena hal tersebut bisa menciptakan rasa aman bagi masyarakat.

Kesepuluh, al-Qur'ân 9:3. Kata khayr lakum pada ayat ini berkaitan dengan perbuatan taubat dari kekufuran dan pengkhianatan. AlSamarqandî memaknai khayr lakum dengan menegakkan perbuatan taubat supaya tidak kembali kepada kekafiran. ${ }^{29}$ Ayat tersebut diturunkan pada saat haji akbar kepada seluruh umat Islam supaya mereka berlepas diri dari orang-orang musyrik dengan segala perilaku yang dilarang oleh Allah. Perbuatan taubat adalah perbuatan yang lebih baik untuk terhindar dari kekufuran dan kemusyrikan. Tetapi ayat ini mengatakan bahwa tidak seluruh orang musyrik harus diperangi. Orang musyrik yang ingin mengenal Islam dan tidak memusuhi Islam tidak boleh diperangi. ${ }^{30}$

Kesebelas, al-Qur'ân 9:41. Perbuatan yang masuk dalam kategori khayr pada ayat ini adalah perintah untuk melaksanakan jihad dengan penuh semangat. Jihad dalam hal ini dilakukan dengan harta dan diri sendiri (jiwa), baik dalam keadaan ringan mapun berat. Hal ini berlaku bagi orang kaya, miskin, kuat maupun lemah sesuai dengan kemampuan masing-masing. Al-Alûsî memaknai khayr lakum dalam ayat ini dengan pemahaman bahwa jihad itu adalah perbuatan yang baik dan merupakan perbuatan yang memuliakan diri sendiri baik di dunia maupun di akhirat. ${ }^{31}$

\footnotetext{
29 al-Samarqandî, Baḥr al-Ulûm, 187.

30 Ayat ini turun 15 bulan sebelum Nabi Muhammad wafat, ini berarti bahwa perintah memerangi orang musyrik baru ditegaskan selama 20 tahun sejak wahyu pertama diturunkan. Sebelum ini al-Qur'ân selalu mengajak pada kedamaian dan menghindari dari peperangan, hal ini disebabkan Karen pentingnya persoalan dan supaya orang Islam terhindar dari kekufuran dan pengkhianatan orang musyrik. AlGhazâlî seperti yang dikutip M. Quraish Shihab mengatakan, bahwa peperangan yang dilakukan oleh Nabi selama 22 tahun lebih hanya mengakibatkan korban sejumlah 200 orang.

31 al-Alûsî, Rûh al-Ma'anî, 194.
} 
Keduabelas, al-Qur'ân 24:60. Kata khayr labunn pada ayat ini berkaitan dengan perbuatan sopan santun dalam hal berpakaian dan menutup aurat bagi perempuan yang sudah tua dan telah berhenti haid serta tidak berhasrat untuk menikah lagi. Sedangkan yang dimaksud dengan pakaian adalah kerudung yang menutup kepala mereka atau pakaian atas yang longgar yang menutup pakaian bagian bawahnya yang dipakai untuk menutup aurat. Hal ini disebabkan karena para perempuan yang sudah tua telah mengalami kesulitan dalam memakai pakaian yang beraneka ragam dan, terlebih, karena alasan jika orang memandang sudah tidak menimbulkan birahi. ${ }^{32}$ Intinya sopan santun yang dikehendaki sebagai perbuatan baik dalam ayat ini adalah terkait dengan budaya tata cara berpakaian seseorang. Budaya berpakaian di antara kelompok manusia pasti memiliki keragaman dan perbedaan. Oleh karena itu, yang menjadi patokan dan ukuran sopan santun serta menutup aurat adalah aturan yang bersumber dari wahyu Allah bukan hanya budaya yang disepakati orang banyak atau masyarakat tertentu.

Berdasarkan penelusuran ayat mengenai kata khayr, penulis menemukan bahwa indikator perbuatan baik/orang baik yang terkandung dalam al-Qur'ân, yaitu ikhlas mengerjakan kebaikan dan berpuasa (al-Qur'ân 2:184), memberi nafkah kepada anak dan keluarganya (al-Qur'ân 2:215), peduli dengan anak yatim (al-Qur'ân 2:220), selalu berkata baik dan pemaaf (al-Qur'ân 2:263), bersedekah kepada fakir miskin (al-Qur'ân 2:271), sabar dalam menerima cobaan dari Allah (al-Qur'ân 4:25), selalu berpegang teguh pada al-Qur'ân dan Hadîth Nabi Muhammad (al-Qur'ân 4:59), bersedekah, amar makruf, dan berdamai dengan sesama manusia (al-Qur'ân 4:114), jujur dalam transaksi, tidak merusak alam dan kehidupan yang ada di bumi (alQur'ân 7:85), bertaubat atas segala dosa dan kesalahan (al-Qur'ân 9:3), jihad dengan harta dan jiwa (al-Qur'ân 9:41), dan sopan santun dalam berpakaian (al-Qur'ân 24:60).

Selanjutnya, setelah langkah identfikasi sebagaimana di atas, penulis melakukan langkah unitizing, reducing, inferring dan analyzing terhadap ayat-ayat al-Qur'ân yang mempunyai korelasi dengan tema kajian ini. Unitizing merupakan langkah menyatukan dan mengelompokkan ayat-ayat berdasarkan tema. Reducing adalah merangkum dan memilih ayat-ayat yang dibutuhkan untuk kemudian dilanjutkan dengan langkah inferring yaitu menarik sebuah kesimpulan. Setelah inferring dilakukan kemudian diakhiri dengan analyzing atau

\footnotetext{
32 Shihab, Tafsîr al-Miṣbâh, Vol. 9, 398. Al-Alûsî, Rûh al-Ma'anî, 358.
} 
menganalisis dan menilai data dari ayat yang telah direduksi sesuai dengan konteks penelitian ini dan mendiskripsikannya secara eksplisit menjadi sebuah teori.

Hasil dari unitizing, reducing, dan analyzing terhadap temuan datadata berupa ayat-ayat al-Qur'ân di atas kemudian diklasifikasikan (ditaksonomi-kan) sesuai dengan karakteristiknya menjadi tiga kategori di bawah ini, yaitu: a) baik dalam kaitannya dengan hubungan manusia dengan Tuhan dinamakan dengan dimensi ilâhîah (ketuhanan atau teosentris); b) baik dalam kaitannya dengan hubungan manusia dengan manusia dan interaksi sosial di masyarakat dinamakan dengan dimensi insâniyah (antroposentris); dan c) baik dalam kaitannya dengan hubungan manusia dengan alam semesta dinamakan dengan dimensi kawnyyah (alam semesta atau kosmosentris).

Dimensi ilâbîyah (ketuhanan) adalah tujuan pendidikan Islam yang harus dicapai setelah mengikuti kegiatan belajar mengajar yang mengandung hubungan antara manusia dengan Tuhannya. Dimensi insâniyah (kemanusiaan) merupakan tujuan pendidikan Islam yang harus dicapai setelah mengikuti kegiatan belajar mengajar yang di dalamnya memuat tata cara dan aturan mengenai hubungan manusia dengan dengan manusia lain (individu dengan individu) dan cara berinteraksi sosial yang baik antara individu dengan masyarakatnya. Sedangkan dimensi kawnyyah (alam semesta) adalah tujuan pendidikan Islam yang harus dicapai setelah mengikuti kegiatan belajar mengajar yang mengandung hubungan antara manusia dengan alam semesta (makro kosmos). Tiga dimensi inilah yang kemudian dinamakan dengan Taksonomi Transenden (Transcendent Taxonomy).

Tiga dimensi Taksonomi Transenden sebagaimana dimaksud di atas diilustrasikan dalam bagan-bagan di bawah ini.

Taksonomi 1:

Dimensi Ilâhîyah (Ketuhanan)

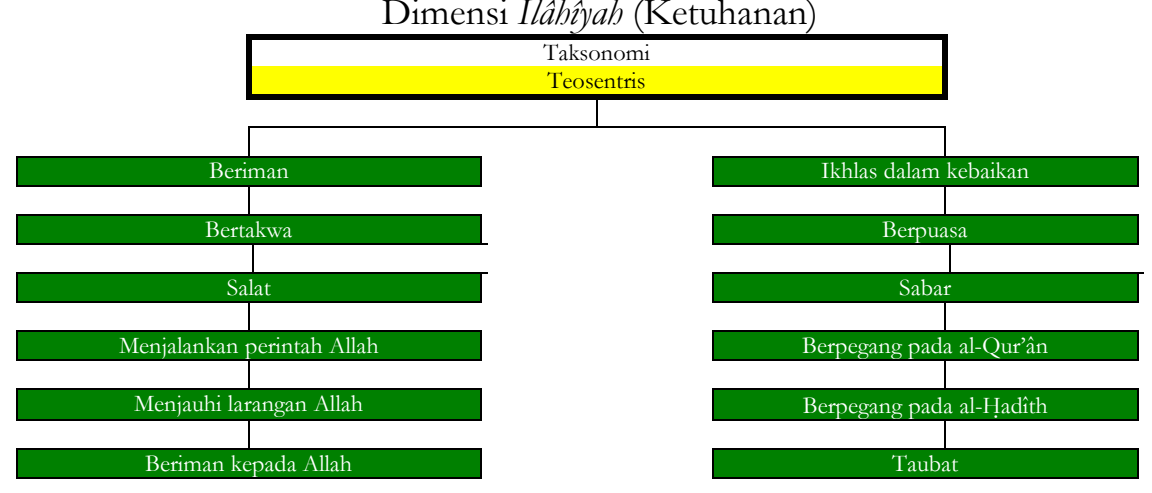




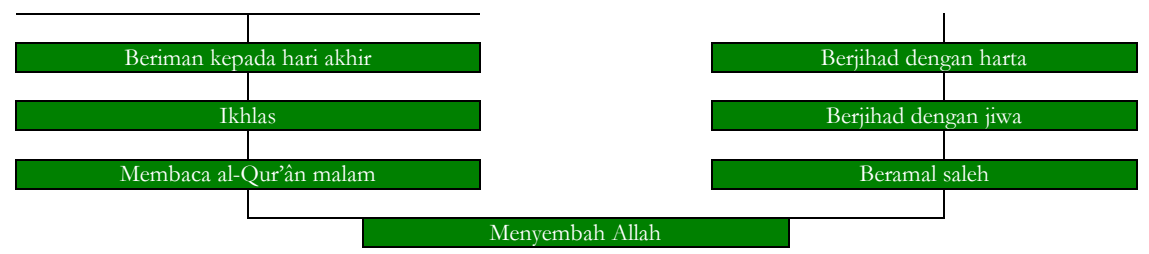

Taksonomi 2: Dimensi Insânîyah (Kemanusiaan)

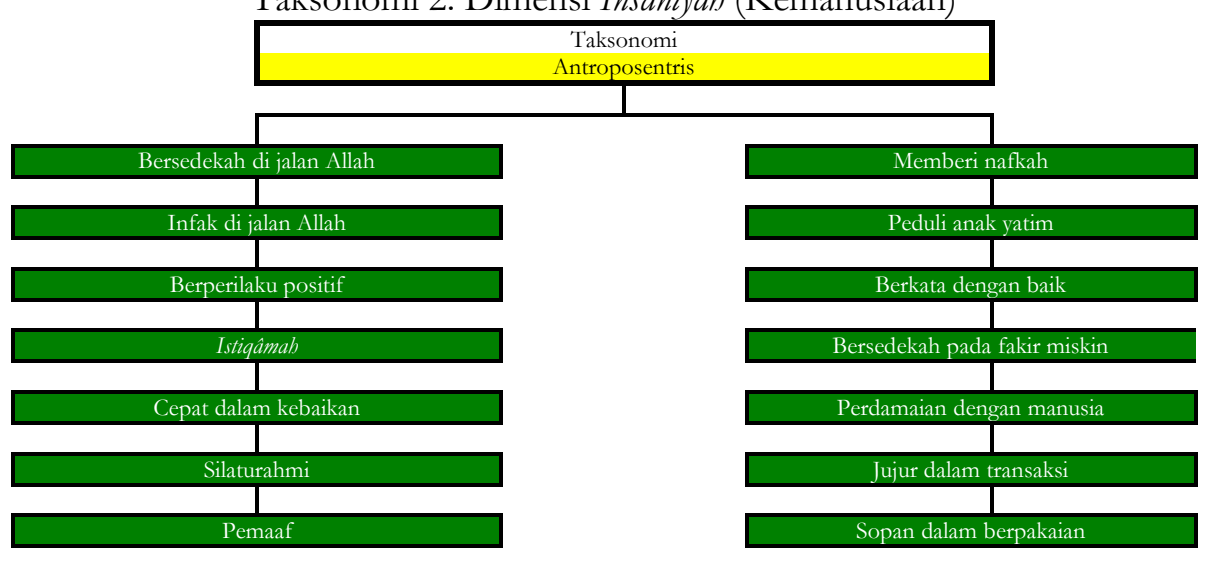

Taksonomi 3: Dimensi Kawnŷyah (Alam Semesta)

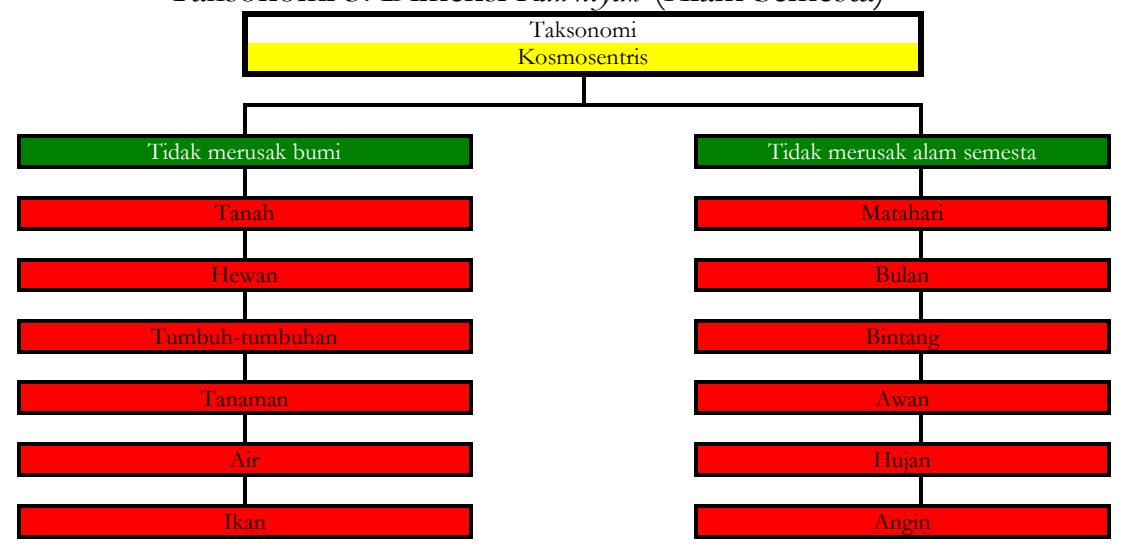

Signifikansi Taksonomi Transenden di Lembaga Pendidikan Islam

Kemajuan zaman yang yang di antaranya ditandai dengan perkembangan sains dan teknologi yang semakin canggih telah menjadikan manusia yang tinggal di berbagai negara berbeda dan benua berbeda menjadi sangat dekat. Hal ini menjadi tantangan tersendiri bagi lembaga pendidikan Islam yang dituntut mampu menyiapkan peserta didiknya agar bisa berbuat banyak dan berkontribusi positif serta signifikan dalam mewarnai perubahan 
zaman.

Penulis berpendapat bahwa tujuan pendidikan yang menuntut komprehensitas dan universalitas menjadikan konsep mengenai taksonomi transenden-yang memuat tiga dimensi seperti dijelaskan di atas-sangat tepat sebagai bekal peserta didik dalam menjalani kehidupannya sekaligus mampu memecahkan problematika yang yang terjadi di era modern. Dalam kajian ini, penulis akan mengulas secara singkat beberapa problem di era modern [yang oleh sementara pihak diklaim sebagai ekses negatif dari modernitas itu sendiri] yang dapat didekati dengan konsep taksonomi trensendental. Beberapa problem tersebut adalah:

Pertama, krisis spiritual. Di era modern dan global sekarang ini manusia cenderung bersifat materialis, individualis dan pragmatis di mana ukuran kebaikan dan kesuksesan adalah materi. Hal ini diklaim sebagai penyebab semakin jauhnya relasi manusia dengan Tuhan. Akibatnya, muncullah berbagai perbuatan negatif seperti stres, bunuh diri, perang saudara, konflik harta kekayaan, dan konflik kekuasaan. Itu semua membuktikan bahwa manusia harus "didekatkan" kembali kepada Tuhan dengan mengisi hati mereka dengan nilai-nilai ketauhidan serta pemahaman mengenai hakikat dan tujuan hidupnya.

Dalam hal ini taksonomi teosentris sebagai salah satu tujuan pendidikan Islam-sesuai dengan konstruksi al-Qur'ân-dapat menunjukan eksistensi sekaligus memainkan perannya. Lembaga pendidikan Islam dituntut menanamkan nilai-nilai tauhid dan ketakwaan sekaligus mengarahkan peserta didiknya kepada pembiasaan perilaku dan ritual keagamaan secara baik, benar, dan konsisten. Diharapkan pada akhirnya nanti peserta didik akan mencapai predikat mubsinûn.

Kedua, krisis kemanusiaan. Tidak dapat dipungkiri bahwa tidak adanya sekat dalam interaksi antarmanusia modern sekarang ini selain berdampak positif juga berekses negatif. Interaksi antarindividu melalui media sosial di dunia tidak jarang berujung kepada perbuatan asusila dan pelanggaran norma-norma kemanusiaan. Di sinilah pendidikan Islam ditantang untuk memiliki visi dan misi yang mampu menjadikan masyarakat plural tersebut menjadi masyarakat dengan tatanan yang harmonis, saling melengkapi yang menjamin kebersamaan, keteraturan, keamanan, dan keselarasan.

Teori taksonomi transenden melalui konsep taksonomi antroposentrisnya mendesain tujuan pendidikan Islam yang terkait 
dengan hubungan manusia sedemikian rupa. Hal tersebut bertujuan agar norma dan nilai dalam kehidupan bermasyarakat dijunjung tinggi serta dipedomani oleh peserta didik. Dalam hal ini, sebagai contoh, peserta didik diajarkan untuk membiasakan diri bersedekah di jalan Allah dengan berbagai bentuknya.

Secara ekplisit, peserta didik diajari untuk, misalnya, bersilaturahmi dengan sesama manusia, menjalin keharmonisan dengan cara berdamai dengan orang lain jika ada perbedaan serta jujur dalam bertransaksi, cepat dalam melaksanakan kebaikan, selalu berpikir positif, menjadi orang yang pemaaf, berkata baik, dan sopan santun dalam berpakaian. Hal tersebut bertujuan agar peserta didik memiliki kepekaan sosial yang tinggi kepada sesama manusia sehingga mereka tidak hanya menjadi manusia yang saleh secara ritual dan spiritual namun juga saleh secara sosial. Nilai-nilai luhur dalam pendidikan Islam tersebut diharapkan mampu memberikan jawaban terhadap krisis kemanusiaan yang terjadi di era modern ini.

Ketiga, kerusakan alam. Eksploitasi dan pemanfaatan sumber kekayaan alam yang berlebihan dan tidak terkendali telah mengakibatkan rusaknya ekosistem yang juga berakibat kepada terjadinya bencana alam yang menelan banyak korban jiwa manusia dan harta benda. Hal ini menjadi tantangan tersendiri sekaligus tanggung jawab bagi pendidikan Islam untuk bagaimana ia mampu menyiapkan peserta didiknya agar berinteraksi dengan alam semesta secara bajik dan bijak.

Teori taksonomi transenden kosmosentris mengajarkan supaya peserta didik tidak melakukan kerusakan di muka bumi baik di daratan maupun di lautan. Hal lain yang harus disiapkan oleh lembaga pendidikan Islam adalah ilmu pengetahuan yang bisa digunakan untuk memanfaatkan sumber daya dan kekayaan alam secara arif. Ilmu pengetahuan tersebut harus menekankan bahwa alam bukanlah objek perahan yang dapat diperlakukan dengan sewenang-wenang hanya untuk memuaskan nafsu manusia. Nilai-nilai kearifan dalam pemanfaatan sumber daya alam dengan demikian menjadi keniscayaan yang harus ditanamkan di jiwa peserta didik. Jika nilai-nilai kebajikan dan kebijakan tersebut tertanam dengan baik, maka diharapkan peserta didik akan memberikan solusi bagi krisis ekosistem yang saat ini melanda bumi.

Dalam konteks temuan terbaru dalam artikel ini, kajian tentang taksonomi tujuan pendidikan Islam dalam perspektif al-Qur'ân pada 
artikel ini disebut dengan "Taksonomi Transenden", yaitu klasifikasi tujuan pendidikan Islam dengan tiga dimensi yang bersumber dari wahyu Allah (al-Qur'ân), yang terdiri dari dimensi ilâhîyah (ketuhanan atau teosentris), dimensi insânyyah (kemanusiaan atau antroposentris) dan dimensi kawnyyah (alam semesta atau ekosentris). Temuan dalam kajian ini dapat dilihat pada skema yang dipaparkan sebagai berikut:

Skema Proses Temuan Teori Taksonomi Tujuan Pendidikan Islam dalam Perspektif al-Qur'ân
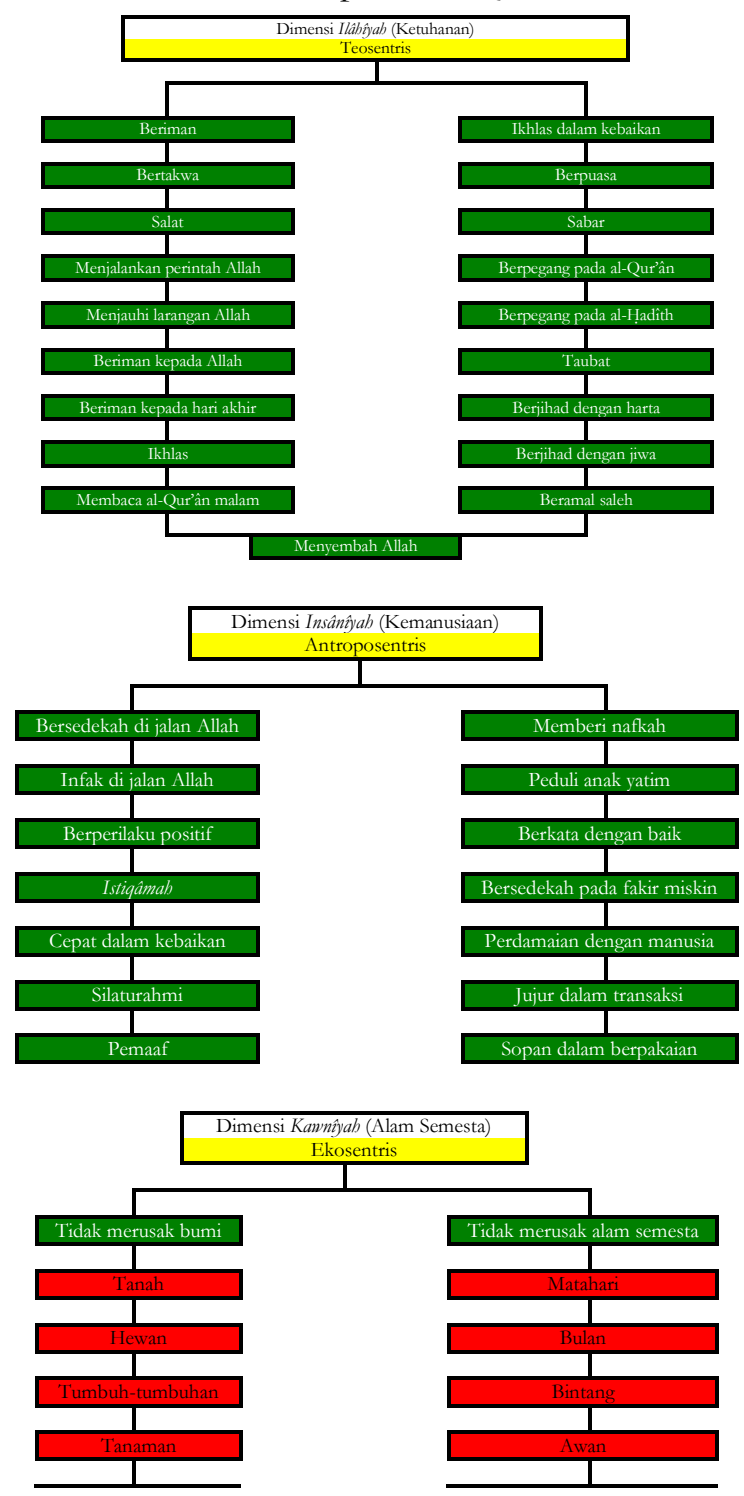

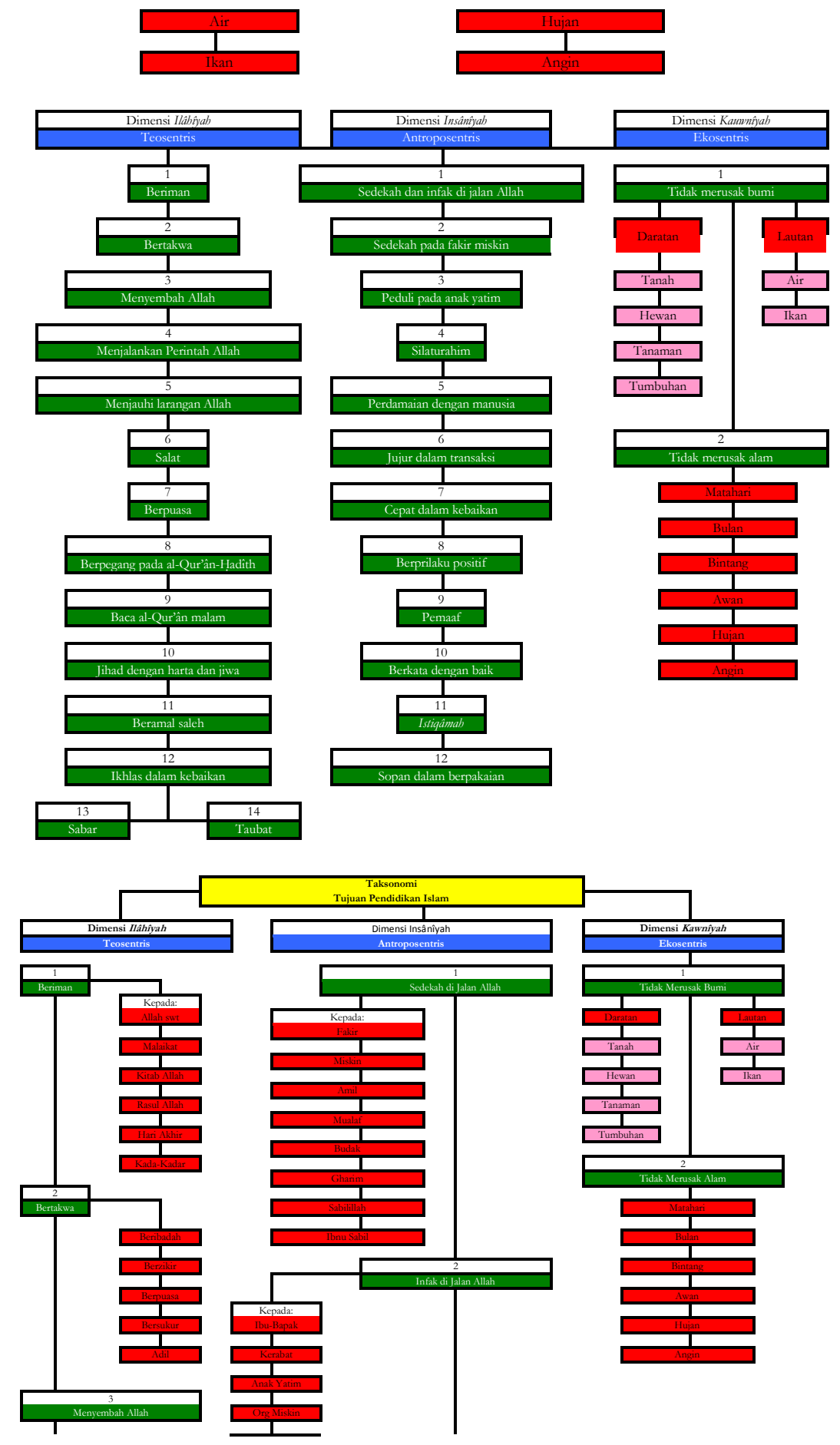


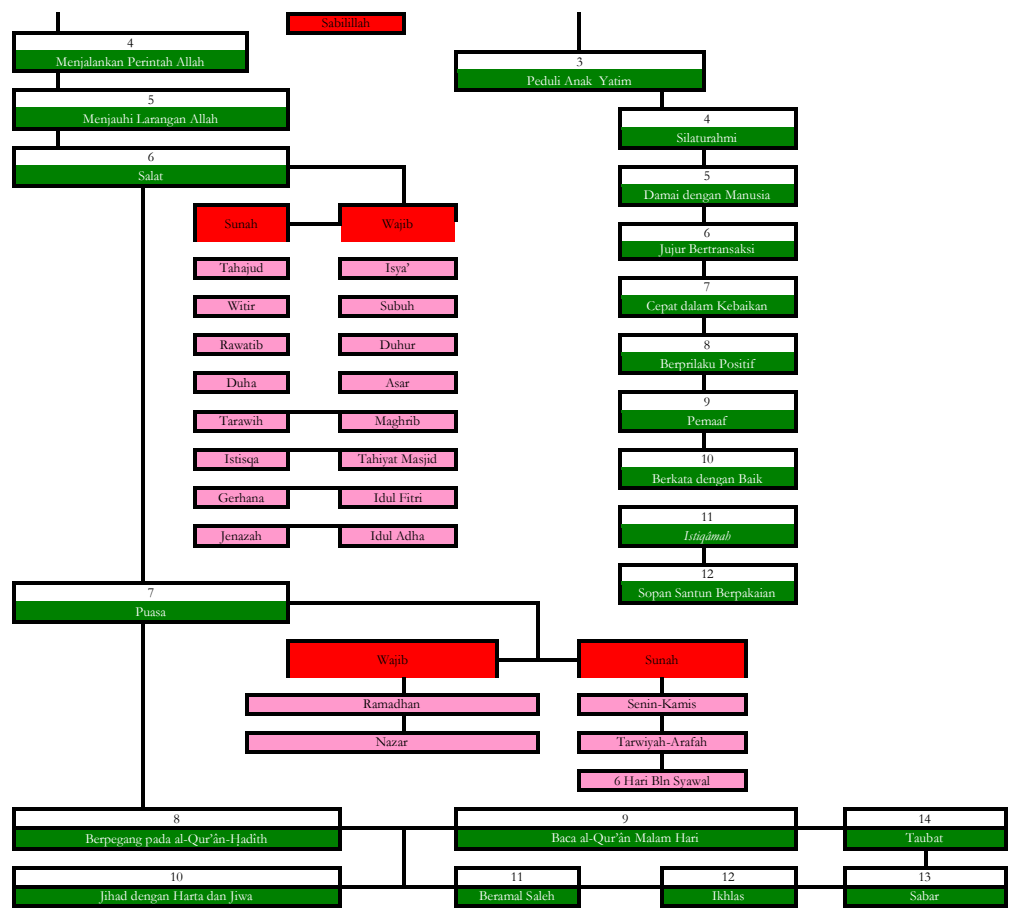

Kajian tentang taksonomi tujuan pendidikan Islam dalam perspektif al-Qur'ân di atas masih perlu untuk dikembangkan dengan klasifikasi-klasifikasi yang lebih rinci dan spesifik, di mana hal tersebut belum dilakukan karena keterbatasan penelitian ini. Namun demikian, paling tidak, kajian ini menjadi salah satu bagian pembuka bagi kajiankajian serupa yang lebih komprehensif.

Hasil temuan teori taksonomi tujuan pendidikan Islam dalam perspektif al-Qur'ân ini jika dikomparasikan dengan tujuan pendidikan yang dikemukakan oleh para tokoh-tokoh pendidikan sebelumnya akan diketahui posisi dan kedudukan kajian ini yang dipaparkan dalam tabel sebagai berikut:

Tabel

Komparasi antara Taksonomi Tujuan Pendidikan Islam dengan Tujuan Pendidikan Islam Konstruksi Para Tokoh Pendidikan

\begin{tabular}{|l|l|}
\hline \multicolumn{1}{|c|}{$\begin{array}{c}\text { Tujuan Pendidikan Islam } \\
\text { Konstruksi Tokoh Pendidikan }\end{array}$} & \multicolumn{1}{|c|}{$\begin{array}{c}\text { Taksonomi Tujuan } \\
\text { Pendidikan Islam Perspektif } \\
\text { al-Qur'ân }\end{array}$} \\
\hline $\begin{array}{l}\text { A. Masa Klasik (650-1800 M) } \\
\text { 1. Membekali manusia dengan akhlak } \\
\text { 2. Meraih kehidupan dunia dan }\end{array}$ & $\begin{array}{l}\text { Dimensi Ilâhîah (ketuhanan) } \\
\text { 1. Beriman } \\
\text { 2. Bertakwa }\end{array}$ \\
\hline
\end{tabular}




\begin{tabular}{|c|c|}
\hline $\begin{array}{l}\text { akhirat } \\
\text { 3. Mencari ilmu sebagai bekal hidup } \\
\text { Mengembangkan potensi manusia } \\
\text { B. Masa Modern (1800-sekarang) } \\
\text { 1. Perubahan perilaku manusia } \\
\text { 2. Memberi bekal hidup manusia } \\
\text { 3. Optimalisasi potensi fitrah } \\
\text { 4. Pelestarian nilai-nilai keislaman } \\
\text { 5. Pengembangan sumber daya } \\
\text { manusia } \\
\text { 6. Mengembangkan potensi fitrah } \\
\text { manusia }\end{array}$ & $\begin{array}{l}\text { 3. Menyembah Allah } \\
\text { 4. Menjalankan perintah Allah } \\
\text { 5. Menjauhi larangan Allah } \\
\text { 6. Salat } \\
\text { 7. Berpuasa } \\
\text { 8. Berpegang teguh pada al- } \\
\text { Qur'ân dan al-Hadîth } \\
\text { 9. Membaca al-Qur'ân pada } \\
\text { malam hari } \\
\text { 10. Jihad dengan harta dan jiwa } \\
\text { 11. Beramal saleh } \\
\text {.I2. Ikhlas melaksanakan kebaikan } \\
\text { 13. Sabar } \\
\text { 14. Taubat } \\
\text { B. Dimensi Insânîah } \\
\text { (kemanusiaan) } \\
\text { Sedekah dan infak di jalan Allah } \\
\text { Sedekah pada fakir miskin } \\
\text { Peduli pada anak yatim } \\
\text { Silaturahmi } \\
\text { Perdamaian dengan manusia } \\
\text { jujur dalam transaksi } \\
\text { Cepat dalam melaksanakan } \\
\text { kebaikan } \\
\text { Berperilaku positif } \\
\text { Pemaaf } \\
\text { Berkata dengan baik } \\
\text { Istiqâmah } \\
\text { Tidak merusak bumi } \\
\text { Sopan dalam berpakaian } \\
\text { C. Dimensi Kawniyah (alam } \\
\text { semesta) } \\
\text { Tidak merusak bumi } \\
\text { 1.rusak alam semesta }\end{array}$ \\
\hline
\end{tabular}

Tabel komparasi di atas menjelaskan perbedaan antara taksonomi tujuan pendidikan Islam dalam perspektif al-Qur'ân dengan teori yang telah ada sebelumnya yang dikemukakan oleh para tokoh pendidikan Islam. Hal ini membuktikan, bahwa penelitian ini mempunyai kedudukan yang urgen sebagai pelengkap dan pengembangan teori yang telah ada sebelumnya. 


\section{Penutup}

Taksonomi transenden merupakan konsep baru yang ditemukan melalui penelitian terhadap ayat-ayat al-Qur'ân dengan pendekatan tafsir tematik yang menyatakan bahwa tujuan pendidikan Islam mencakup tiga dimensi, yaitu dimensi ketuhanan (ilâhîyah atau teosentris), dimensi kemanusiaan (insânîyah atau antroposentris), dan dimensi alam semesta (kawnîyah atau kosmosentris). Signifikansi teori taksonomi transenden dalam praktik pendidikan Islam adalah sebagai rujukan dalam merumuskan tujuan pendidikan Islam, di samping untuk membekali peserta didik kemampuan dalam menghadapi persaingan global di zaman modern dan menemukan solusi konstruktif terhadap berbagai krisis kehidupan, seperti krisis spiritual, krisis kemanusiaan, dan kerusakan alam semesta.

\section{Daftar Rujukan}

Abdullah, M. Amin. Falsafah Kalam di Era Postmodernisme. Yogyakarta: Pustaka Pelajar, 1995.

Alûsî (al), Shihâb al-Dîn Mạmmûd. Ruhh al-Ma'ânî fî̀ Tafsîr al-Qur'ân alKarim wa Sab' al-Mathânî. Beirut: Dâr Ihyâ' al-Turâth al-'Arabî, 2008.

Anderson, Orin W. dan Krathwohl, David R. A Taxonomy for Learning, Teaching and Assassing: A Revision of Bloom's Taxonomy of Educational Objective. New York: Longman Press, 2001.

Anderson. International Encyclopedia of Teaching and Teacher Education. Oxford: Pergamon Press, 1995.

Bâqî (al), Fuâd 'Abd. Mu'jam al-Mufahrâs li Alfàz al-Qur'ân. Kairo: Dâr al-Fikr, 1992.

Daradjat, Zakiyah. Ilmu Pendidikan Islam. Jakarta: Bumi Aksara, 2009. Jawzî (al), Ibn. Zâd al-Masîr fì 'Tlm al-Tafsîr. Kairo: Dâr Ibn Hạzm, 2013. Kathîr, Ibn. Tafsir al-Qur'ân al-'Ažîm. Damaskus: Dâr al-Ṭayyibah, 1999.

Maḥallî̀ (al), Jalâl al-Dîn dan Suyûṭ̂i (al), Jalâl al-Dîn. Tafsîr Jalalayn wa Lubâb al-Nuqûl fî̀ Asbâb al-Nuzûul 'alâ Hâmish al-Qur'ân al-Karîm. Kairo: Dâr Ibn Kathîr, 2008.

Mâwardî (al), Abû al-Ḥasan 'Alî b. Muhammad b. Muhammad b. Habîb al-Bașrî al-Baghdâdî. al-Nukat wa al-Uyûn. Beirut: Dâr alKutub al-'Ilmîyah, 2010.

Muhaimin. Paradigma Pendidikan Islam: Upaya Mengefektifkan Pendidikan Agama di Sekolah. Bandung: Rosdakarya, 2001. 
Naysâbûrî (al), Nizâam al-Dîn al-Ḥasan b. Muhammad b. Hụsayn alQummî. Gharâib al-Qur'ân wa Raghâib al-Furqân, Vol. 1. Beirut: Dâr al-Kutub al-'Ilmîyah, 2010.

Rahman, M. Afẓalur. Indeks al-Qur'ân. Jakarta: Amzah, 2009.

Râzî (al), Fakhr al-Dîn. Mafâtîh al-Ghayb. Beirut: Dâr al-Fikr, 1981.

Samarqandî (al), Abû al-Layth Naṣr al-Dîn Muhammad b. Aḥmad b. Ibrâhîm. Baḥr al-Ulûm. Beirut: Dâr al-Kutub al-'Ilmîyah, 2010.

Shihab, M. Quraish. Tafsîr al-Mişbâh, Pesan, Kesan dan Keserasian alQur'ân, Vol. 1. Jakarta: Lentera Hati, 2000.

Tabarî (al), Abû Ja'far. Jâmi‘ al-Bayân fî̀ Ta'mîl al-Qur'ân, Vol. 1. Kairo: Mu'assasat al-Risâlah, 2000. 